\title{
Penerapan Aplikasi Classroom pada Mata Pelajaran Qur'an Hadits
}

\author{
Moh. Miftakhul Huda', Ashif Az Zafi ${ }^{2}$ \\ ${ }^{12}$ Institut Agama Islam Negeri Kudus, Indonesia \\ ${ }^{1}$ Mifta.huda0409@gmail.com
}

\begin{abstract}
Abstrak:
Pembelajaran e-learning merupakan pemanfaatan media pembelajaran menggunakan internet, untuk mengirimkan serangkaian solusi yang dapat meningkatkan pengetahuan dan keterampilan dalam menggunakan metode pembelajaran. Dalam Penelitian ini bertujuan untuk mengetahui penerapan aplikasi classroom pada mata pelajaran Qur'an Hadits di MA NU Al Hidayah. Dalam penelitian juga membahas dampak atau faktor terkait adanya penggunaan aplikasi classroom. Penelitian ini menggunakan jenis kualitatif analisis deskriptif dengan jenis penelitian berupa studi lapangan di Sekolah MA NU Al Hidayah, dilanjutkan dengan proses pengumpulan data, penelitian ini menggunakan teknik dokumentasi dan wawancara bersama guru pengampu mata pelajaran Qur'an Hadits dan beberapa peserta didiknya. Subjek penelitian adalah guru pengampu mata pelajaran Qur'an Hadits di MA NU Al Hidayah dan beberapa peserta didiknya. Hasil penelitian menunjukkan bahwa: (1) aplikasi ini sangat berpengaruh dalam pembelajaran daring. (2) adanya hambatan-hambatan yang terjadi dalam pembelajaran. Pengaruh adanya penelitian ini dapat mengatasi kendala-kendala yang terjadi dalam pembelajaran berlangsung atau mencari inovasi terbaru untuk kedepannya.
\end{abstract}

Kata Kunci: E-learning, classroom, Qur'an Hadis

\begin{abstract}
:
E-learning is the use of learning media using the internet, to send a series of solutions that can increase knowledge and skills in using learning methods. In this study, the aim of this research is to determine the application of the classroom application in the Qur'an Hadith subject at MA NU Al Hidayah. This research also discusses the impact or factors related to the use of the classroom application. This research used a qualitative descriptive analysis type with the type of research in the form of field studies at the MA NU Al Hidayah School, followed by the data collection process, this study used documentation techniques and interviews with the teachers who taught the Qur'an Hadith subjects and some of their students. The research subjects were teachers of Qur'an Hadith subjects at MA NU Al Hidayah and some of their students. The research subjects were teachers of Qur'an Hadith subjects at MA NU Al Hidayah and some of their students. The results showed that: (1) this application is very influential in online learning. (2) there are obstacles that occur in learning. The effect of this research can overcome the obstacles that occur in ongoing learning or find new innovations for the future.
\end{abstract}

Keywords: E-learning, Classroom, Learning, Qur'an Hadist 


\section{Pendahuluan}

Pendidikan adalah suatu kegiatan yang dilakukan dengan penuh kesadaran dan penuh tanggung jawab serta terencana dengan baik dalam memberikan pembinaan dan bimbingan pada peserta didik. Dalam bimbingan dan pembinaan tersebut tidak hanya berpacu pada intelektualnya saja, namun juga pada segi emosionalnya. Dalam suatu bimbingan dan pembinanaan tersebut dapat dilakukan dari keluarga terdekat, sekolah dan masyarakat sekitar, sehingga dapat mewujudkan perubahan yang lebih positif.

Pendidikan agama merupakan suatu pembentukan dari moral dan karakter pada peserta didik. Sehingga ketika memberikan pengetahuan keagamaan kepada peseta didik, guru harus menjadi suri tauladan yang baik bagi anak didiknya. Sebagai salah satu figur tauladan, seorang pendidik harus mampu menuntut sikap yang baik atau mempunyai etika yang baik dalam perbuatan ataupun budi pekerti yang luhur. Sebab, seorang guru selalu menjadi sorotan bagi anak didiknya. Guru yang tidak bisa menjadikan dirinya sebagai suri tauladan bagi anak didiknya maka guru tersebut itu dianggap gagal dalam menjalakan tugas utamanya sebagai seorang pendidik. (Ivah, 2020: 2)

Adapun tujuan dari pendidikan Islam yaitu untuk menginformasikan, mentransformasikan serta menginternalisasikan tentang adanya nilai-nilai Islam. Dengan demikian maka, pendidikan Islam dapat mengajarkan adanya moral positif yang berakar pada suatu nilai-nilai kajian Islami, sebagai pendorong moral reasioning atau penalaran akhlak yang sangat dibutuhkan untuk menentukan pilihan dan keputusan terkait masalah-masalah yang baru muncul dalam suatu proses pembangunan ini. Oleh karena itu, dalam pendidikan Islam harus mampu menyajikan learning experiences atau terkait pengalaman belajar yang dapat merangsang kesadaran dan komitmennya mengenai masalah sosial dan etika dalam bermasyarakat, yang dapat memungkinkan ikut mengatasi kendala yang sedang dialami pada masa sekarang. ${ }^{1}$

Selanjutnya, pada penelitian Bekti Mulatsih sebelumnya pada artikelnya menjelaskan tentang Penerapan Aplikasi Classroom, Google Form, dan Quizizz Dalam Pembelajaran Kimia Di Masa Pandemi Covid-19. Dalam artikel tersebut menjelaskan cakupan subjek penelitian yaitu terdapat pada mata pelajaran kimia di sekolah saja dan dalam pembahasan kurang

1 (Afidatul Umroh, "Peran Guru Pendidikan Agama Islam Dalam Menginternalisasikan Nilai-Nilai Pendidikan Islam Untuk Menumbuhkan Sikap Toleran Antar Umat Beragama Siswa Kelas XI SMK N 5 Yogyakarta." UIN Sunan Kalijaga Yogyakarta (2015), h. 3) 
dispesifikasikan lebih lanjut, sehingga terdapat berbagai permasalahan, pembahasan dalam artikel ini memberi batasan terkait subjek yang diambil yaitu pada guru (tutor) dan kepala sekolah SMAN. Artikel yang dijelaskan oleh Bekti Mulatsih tersebut diantaranya yaitu mengenai tentang cara pengaplikasian beberapa aplikasi pembelajaran sistem daring yang berupa aplikasi zoom, classroom, google form, quizizz, whatsapp, dan telegram. Dalam artikel tersebut yang membedakan dari artikel penelitian ini yaitu dalam pembahasan artikel tersebut tidak terfokus pada satu aplikasi pembelajaran daring namun terfokus kepada lebih dari satu aplikasi pembelajaran daring pokok dari tahapan ini yaitu adanya sebuah tampilan sosok fisik dari seorang peserta didik. ${ }^{2}$

Adapun tujuan adanya penelitian ini yaitu untuk mengetahui bagaimana penerapan aplikasi classroom pada mata pelajaran Qur'an Hadits di MA NU Al Hidayah. Dalam penelitian ini juga membahas faktor pendukung dan penghambat seta solusinya terkait adanya penggunaan aplikasi classroom. Untuk metode yang akan digunakan dalam penelitian tersebut yaitu menggunakan penelitian metode kualitatif analisis deskriptif dengan jenis penelitian berupa studi lapangan di Sekolah MA NU Al Hidayah. Kemudian, dilanjutkan dengan proses pengumpulan data dengan cara penelitian ini menggunakan teknik dokumentasi dan melalui wawancara bersama dengan pihak sekolah yaitu guru yang mengampu pada mata pelajaran Qur'an Hadits dan beberapa peserta didiknya. Terkait subjek penelitian ini lebih ditekankan kepada calon guru PAI yang memiliki posisi yang strategis sebagai ujung tombak adanya pelaksanaan kebijakan pendidikan di sekolah, karena sesuai dengan Peraturan Pemerintah Nomor 55 Tahun 2007 tentang Pendidikan Agama dan Keagamaan menjelaskan bahwa satuan pendidikan pada semua jenjang dan jalur pendidikan di Indonesia pasti terdapat pendidikan Agama Islam yang diampu oleh guru PAI. Maka dari itu sebuah pendidikan agama Islam menjadi sangat penting dalam suatu lembaga pendidikan di Indonesia yang mayoritas beragama Islam. ${ }^{3}$

Dengan adanya penelitian ini dapat menjadi solusi bagi seorang calon guru PAI agar dapat memaksimalkan dengan baik dalam pembelajaran online ketika terdapat kendala dalam pembelajaran tatap muka dikelas seperti tahun ini yang terkendala dengan adanya wabah covid19 yang berefek pada dunia kependidikan, maka guru harus pandai memutar otak untuk

2 (Bekti Mulatsih, "Penerapan Aplikasi Google Classroom, Google Form, Dan Quizizz Dalam Pembelajaran Kimia Di Masa Pandemi Covid-19 Application of Google Classroom , Google Form and Quizizz in Chemical Learning During the Covid-19 Pandemic." ideguru: Jurnal Karya Ilmiah Guru 5(1), 2020: 16)

3 (Naili Nur Fitrotun, Moh Miftakhul Huda, dan Achmad Ali Fikri, "Persepsi Calon Guru PAI Terhadap Merdeka Belajar.” Tadris:Jurnal Pendidikan Islam 14(1), 2019: 238) 
mencari pengganti metode pembelajaran yang asal mulanya tatap muka yaitu dengan metode pembelajaran daring dengan menggunakan salah satu aplikasi pembelajaran misalnya classroom sebagai bahan pengganti media pembelajaran, agar pembelajaran tetap berlangsung dengan baik meskipun dengan cara daring (online).

\section{Metode}

Adapun dalam penelitian ini metode yang digunakan merupakan metode kualitatif, informan yang dijadikan pada penelitian ini adalah guru yang mengampu mata pelajaran Qur'an Hadits MA NU Al Hidayah dan beberapa peserta didiknya. Penelitian ini dengan menggunakan sebuah teknik pengumpulan data yang melalui wawancara langsung dan observasi. Teknik analisis data, klasifikasi data, dan penyimpulan data.

\section{Pembahasan}

\section{Pengertian Al-Qur’an, Pembelajaran, Model Pembelajaran dan Pembelajaran Daring}

Al-Qur'an merupakan kitab suci umat Islam dan sebagai salah satu mu'jizatnya Nabi Muhammad SAW yang sangat agung (terbesar) ternyata tidak ada seorangpun yang mampu membuat atau menulis semisal Al-Qur'an. Pada awalnya seluruh manusia ditanding untuk mencoba membuat sebuah tandingan yang serupa dengan Al-Qur'an, namun, tidak ada seorangpun yang dapat menandinginya dan melakukannya. Selanjutnya oleh Al-Qur'an mereka ditantang untuk membuat tandingan yang lebih sederhana, yaitu seluruh manusia itu diminta untuk membuatkan sepuluh surah saja yang serupa dengan adanya Al-Qur'an baik fashahah maupun balaghahnya. Dan ternyata tidak ada manusia yang mampu melakukannya. Maka akhirnya Al-Qur'an meminta kepada seluruh manusia untuk membuatkan hanya satu surah saja yang seperti Al-Qur'an. Namun, ternyata walaupun hanya satu surah tidak ada seorangpun yang mampu membuat tandingannya daripada Al-Qur'an tersebut. ${ }^{4}$

Pembelajaran secara sederhana berarti sebagai suatu usaha yang memengaruhi emosi, intelektual, dan spiritual seseorang, agar dapat belajar dengan kehendaknya sendiri atau kemauannya sendiri. Melalui adanya pembelajaran akan terjadi sebuah proses pengembangan tentang moral keagamaan, aktivitas, serta kreativitas peserta didik melalui berbagai suatu interaksi dan pengalaman belajar. Pembelajaran berbeda dengan adanya prinsip mengajar yang

${ }^{4}$ (Haniq Amamah, "PENINGKATAN PRESTASI BELAJAR SISWA MAPEL AL-QUR'AN HADITS MATERI SURAH AL-BAYYINAH MELALUI PENERAPAN METODE DRILL KELAS VI MI NASHRIYAH MRANGGEN TAHUN." UNIVERSITAS ISLAM NEGERI WALISONGO, 2016: 2) 224 | Ilmu Al-Qur'an (IQ) Jurnal Pendidikan Islam | Volume 04 No.2 2021 
pada prinsipnya menggambarkan sebuah aktivitas guru, sedangkan pembelajaran menggambarkan suatu aktivitas peserta didik. ${ }^{5}$

Menurut Trianto Model Pembelajaran merupakan sebuah system perencanaan atau suatu pola yang digunakan sebagai pedoman dalam melaksanakan suatu adanya proses pembelajaran dikelas atau pembelajaran dalam tutorial. Menurut Sagala model pembelajaran merupakan suatu kerangka konseptual yang melukiskan adanya berbagai prosedur yang sistematis dalam mengorganisasikan pengalaman belajar peserta didik upaya mencapai suatu tujuan pembelajaran yang sudah ditentukan atau ditargetkan, adapun fungsinya sebagai pedoman bagi perancang pembelajaran dan seorang guru dalam merencanakan serta melaksanakan suatu aktivitas belajar mengajar. Sedangkan pembelajaran menurut Muhammad Surya dalam Isjoni yaitu suatu proses perubahan yang dilakukan oleh seorang individu dalam memperoleh suatu perubahan perilaku yang baru secara keseluruhan, sebagai sarana hasil dan pengalaman individu itu sendiri dalam berinteraksi dengan lingkungan sekitarnya. ${ }^{6}$

Penerapan model pembelajaran menjadi salah satu faktor utama dalam terbentuknya suatu proses pembelajaran. Hal tersebut dikarenakan ketika akan menerapkan model pembelajaran yang sesuai maka proses pembelajaran dan hasil belajarnya pun akan memenuhi target yang diharapkan. Model pembelajaran merupakan seperangkat rencana atau pola yang dapat dipergunakan dalam merancang tentang bahan-bahan pembelajaran serta membimbing aktivitas pelajaran didalam kelas atau di tempat yang lain dalam melaksanakan aktivitasaktivitas belajar mengajar. ${ }^{7}$

Pembelajaran daring atau yang disebut dengan pembelajaran online atau e-Learning yakni pembelajaran yang dapat mencakup suatu pembelajaran secara formal maupun informal. E-Learning merupakan singkatan dari Electronic Learning yang berarti belajar secara elektronik. ${ }^{8}$ E-Learning yaitu suatu media teknologi informasi dan komunikasi yang dapat memiliki kemampuan dalam mengembangkan suatu aplikasi proses belajar mengajar. Dengan demikian E-Learning adalah suatu pembelajaran yang pelaksanaannya didukung oleh jasa teknologi seperti gawai, audio, video, handphone atau computer. Pembelajaran dengan cara daring dianggap menjadi salah satu solusi untuk kegiatan belajar mengajar agar tetap jalan di

\footnotetext{
2018: 55)

5 (Abdul Rahman Tibahary, dan Muliana, “MODEL-MODEL PEMBELAJARAN INOVATIF” 1(03),

${ }^{6}$ (Ina Magdalena, dkk 2020. "Implementasi Model Pembelajaran Daring Pada Masa Pandemi Covid-19 Di Kelas Iii Sdn Sindangsari Iii.” Pandawa : Jurnal Pendidikan dan Dakwah 3(1), 2020: 120)

${ }^{7}$ (Nanang Martono, Metode Penelitian Sosial. (Jakarta: Rajawali Pers, 2015): 71)

8 (W. Winarno, dan J Setiawan, "Penerapan Sistem E-Learning Pada Komunitas Pendidikan Sekolah Rumah (Home Schooling).” Jurnal ULTIMA InfoSys, 4(1) 2013: 45)
} 
tengah pandemi corona. Beberapa penelitian menunjukkan dengan adanya pembelajaran online menghasilkan yang signitifikan ${ }^{9}$, namun dalam proses pembelajaran online bukan hanya belajar yang informal atau tidak terstruktur seperti yang terjadi dalam kehidupan sehari-hari saat orang mengakses internet. Sehingga para pakar mengarahkan dalam seluruh sumber daya bisa dikerahkan dalam terciptanya pendidikan online yang sedang berlangsung ini menjadi topic utama dibidang dunia kependidikan di tahun 2025 . $^{10}$

Seiring dengan adanya perubahan zaman yang serba cepat di semua industri maupun di dunia global,. Terdapat beberapa faktor-faktor seperti pertumbuhan populasi dan kemajuan teknologi dapat menentukan dan mengubah kebutuhan pribadi manusia. Kemajuan yang pesat di bidang iptek juga telah menyebabkan suatu perubahan penting di bidang ekonomi, kesehatan, seni, dan sastra. Adanya beberapa bidang lain yang sangat dipengaruhi oleh kemajuan teknologi dan diharapkan dapat menunjukkan suatu perubahan paradigma di antaranya adalah dibidang dunia kependidikan. Di antara semuanya, yang paling terpengaruh oleh perubahan tersebut adalah anak-anak dan remaja yang juga disebut sebagai Generasi Z atau warga digital. ${ }^{11}$

Adapun perkembangan terkait adanya informasi dan teknologi sangat penting jika mengingat dalam setiap tahun atau bahkan setiap bulan ilmu pengetahuan dan informasi akan selalu berkembang. Dalam perkembangan teknologi informasi dan internet dewasa ini berkembang sangat pesat sehingga, tidak hanya mempengaruhi produk elektronik saja, melainkan juga dalam bidang dunia kependidikan terutama dalam penggunaan metode pembelajaran di pandemi covid-19 ini. Salah satu metode dalam pembelajaran online yang saat ini sedang berkembang dan mulai digunakan adalah google classroom. Google classroom adalah aplikasi yang dikhususkan untuk media pembelajaran online atau istilah lainnya adalah kelas online. Sehingga dapat memudahkan guru dalam membuat, membagikan serta mengelompokkan setiap tugas yang diberikan tanpa menggunakan kertas lagi. Dalam penggunaan google classrom akan membuat proses pembelajaran menjadi lebih efektif terlebih lagi guru dan siswa dapat setiap saat bertatap muka melalui kelas online google classroom

9 (S. Baldwin, Y. H. Ching, and Y. C Hsu. 2018. "Online Course Design in Higher Education.” A Review of National and Statewide Evaluation Instruments 62(1): 2018: 48)

10 (Fauzi, Wildan Nuril Ahmad, and Erni Munastiwi. 2020. "ANALISIS PROSES PEMBELAJARAN BERBASIS ONLINE MASA PANDEMI COVID-19 DI SDIT LUQMAN AL-HAKIM SLEMAN.” 14(2), 2020:174)

11 (Say, Fuat Serkan, and Fatih Serdar Yildirim. 2020. "Flipped Classroom Implementation in Science Teaching." International Online Journal of Education and Teaching 7(2), 2020: 606) 226 | Ilmu Al-Qur'an (IQ) Jurnal Pendidikan Islam | Volume 04 No.2 2021 
ketika proses pembelajaran. Adapun juga peserta didik nantinya dapat belajar, menyimak, membaca, mengirim tugas, dari jarak jauh. ${ }^{12}$

\section{Penerapan aplikasi classroom pada mata pelajaran Qur'an Hadits}

Google classroom merupakan salah satu cara yang dapat digunakan dalam melakukan proses pembelajaran e learning atau daring. Pemanfaatan google classroom dapat melalui berbagai multiplatform yaitu dapat melalui komputer dan dapat melalui gawai (gadget). Google Classroom adalah sebuah aplikasi yang memungkinkan terciptanya ruang kelas di dunia maya. Selain itu, google classroom dapat menjadi sebuah sarana distribusi tugas, submit tugas bahkan dapat menilai tugas-tugas yang dikumpulkan oleh peserta didik. 13

Pada google classroom sesungguhnya dirancang untuk dapat mempermudah interaksi guru dengan siswa dalam dunia maya. Dalam aplikasi ini memberikan kesempatan kepada para guru untuk mengeksplorasi suatu gagasan keilmuan yang dimilikinya kepada siswa. Guru memliki keleluasaan waktu dalam membagikan kajian keilmuan dan memberikan tugas individu kepada siswa selain itu, guru juga dapat membuka ruang diskusi bagi para siswa secara online. Namun demikian, terdapat beberapa syarat yang mutlak dalam mengaplikasikan google classroom yaitu membutuhkan akses internet yang sangat mumpuni atau stabil. Pada aplikasi google ${ }^{14}$ classroom bisa digunakan oleh siapa saja yang terhubung dengan kelas tersebut. Pada kelas tersebut adalah kelas yang didesain oleh guru yang sesuai dengan kelas sesungguhnya atau kelas nyata pada system tatap muka di sekolah. Terkait dengan anggota kelas dalam google classroom bahwa google classroom dapat menggunakan kelas tersedia bagi siapa saja yang memiliki Google Apps for Education, ${ }^{15}$ serangkaian alat produktivitas gratis termasuk gmail, dokumen, dan drive. Pada aplikasi ini google classroom sangat ramah lingkungan. Hal ini dikarenakan siswa tidak lagi menggunakan kertas ketika akan mengumpulkan tugasnya kepada guru mereka. Hal ini sejalan dengan pendapat Herman dalam yang memaparkan bahwa dalam google classroom kelas dirancang bisa membantu guru membuat dan mengumpulkan tugas tanpa adanya

12 (Soni, dkk "Optimalisasi Pemanfaatan Google Classroom Sebagai Media Pembelajaran Di SMK Negeri 1 Bangkinang.” Jurnal Pengabdian Untuk Mu NegeRI 2(1), 2018: 18)

${ }^{13}$ (Zedha Hammi, Skripsi “'Implementasi Google Classroom Pada Kelas Xi Ipa Man 2 Kudus."'Skripsi, Universitas Negeri Semarang, 2017: 45)

14 (Hagermoser Sanetti, Lisa M., Kathleen M. Williamson, Anna C.J. Long, dan Thomas R. Kratochwill. "Increasing In-Service Teacher Implementation of Classroom Management Practices Through Consultation, Implementation Planning, and Participant Modeling." Journal of Positive Behavior Interventions 20(1), 2018: 43)

15 (Tony Vrba, dan Kerry Mitchell, “Contemporary Classroom Innovation: Exploration.” Journal of Instructional Pedagogies, 2019: 6) 
kertas, termasuk salah satu fitur yang menghemat waktu seperti kemampuan untuk membuat salinan google dokumen secara otomatis bagi setiap siswa. Dalam kelas juga bisa membuat folder drive untuk setiap tugas dan setiap siswa, agar semuanya tetap teratur dan tidak berantakan. ${ }^{16}$

Berdasarkan hasil adanya observasi yang dilakukan respon siswa terhadap penerapan penggunaan google classroom maka data yang diperoleh bahwa google classroom sangat berguna dan berpengaruh dalam proses pembelajaran daring ini. Hal ini dibuktikan setelah melakukan observasi dan wawancara kepada informan di MA NU A1 Hidayah. Salah satunya siswa dapat melihat dan membuka materi maupun tugas-tugas yang sudah diupload pada google classroom oleh guru mereka.

Setelah mengadakan observasi di MA NU Al Hidayah melalui wawancara pada informan setempat terdapat hasil penelitian ini yaitu Pelaksanaannya dengan cara melakukan kordinasi dengan guru pada pembelajaran online dan bekerja sama dengan bapak ibu guru wali kelas agar dapat mendata semua siswa yang sudah bisa terhubung (terkoneksi) pada pembelajaran dengan cara mengabsen dan siswa yang belum dapat terhubung, serta mencari sebuah solusi dalam menghadapi kendala tersebut agar kedepannya lebih baik ketika ada system pembelajaran daring lagi.

\section{Faktor pendukung, faktor penghambat dan solusinya dalam penerapan aplikasi}

\section{classroom}

\section{Faktor pendukung dan faktor penghambat dan solusinya}

Faktor yang menjadi pendukung dan suatu cara mengoptimalkan dalam pembelajaran online dengan menggunakan aplikasi classroom ini yaitu tersedianya sarana prasarana disekolah yaitu dengan adanya pemasangan jaringan koneksi internet di sekolahan untuk mensupport system pembelajaran daring online. Sedangkan para peserta didik juga sudah mempunyai media yang berguna untuk mengakses aplikasi yang telah ditentukan oleh guru mata pelajaran tersebut seperti aplikasi classroom yang digunakan untuk pembelajaran daring pada mata pelajaran Qur'an Hadits. Sedangkan faktor penghambatnya yaitu suatu adanya kendala yang dihadapi oleh orang tua peserta didik yaitu adanya suatu penambahan biaya yang digunakan untuk pembelian kuota internet. Solusi yang digunakan dalam mengatasi penghambat pembelajaran online ini yaitu pemanfaatan sarana dan prasarana

${ }^{16}$ (Zedha Hammi, Skripsi “"Implementasi Google Classroom Pada Kelas Xi Ipa Man 2 Kudus.”'Skripsi, Universitas Negeri Semarang, 2017: 162)

228 | Ilmu Al-Qur'an (IQ) Jurnal Pendidikan Islam | Volume 04 No.2 2021 
dengan optimal dapat menunjang efektifitas pembelajaran online, dengan cara pemberian modul pembelajaran untuk materi yang belum tersampaikan, dan untuk sementara bagi siswa yang belum bisa terhubung dalam pembelajaran disarankan untuk datang kesekolah untuk mengambil tugas. ${ }^{17}$

Sementara sisi negatif atau disebut dengan hambatan terciptanya pembelajaran daring atau online. Hambatan yang terjadi pada sistem pembelajaran daring ini salah satunya adalah tidak pada semua peserta didik memiliki tingkat kepahaman yang sama. Sehingga menciptakan ketidak pahaman dalm memahami materi. Bagi peserta didik yang rajin serta mudah menyerap informasi maka cara belajar daring akan dengan mudah diserap, namun bagi yang kurang terbiasa dengan cara itu, kemungkinan akan menjadikan kesulitan tidak hanya waktu menyerap pembelajaran berbasis daring yang disampaikan gurunya tetapi juga kemampuan beradaptasi dengan aplikasi teknologi yang digunakan dalam kegiatan belajar mengajar (KBM). Bagi sekolah dalam menjalankan pembelajaran online membutuhkan perlatan dan teknis seperti computer, paket data internet menjadi kendala terutama mereka yang tinggal di desa dan baru menerapkan pembelajaran daring. Sekolah harus menyiapkan tim inti dalam merancang proses pembelajaran online. Bagi guru jelas menggunakan aplikasi berbasis internet membutuhkan persiapan yang matang ketimbang mengajar secara langsung di dalam kelas. Kemudian banyak orang tua yang tidak menyanggupi pembelajaran menggunakan media seperti zoom meeting, google meet, google classroom di karenakan handphone tidak dapat menginstal aplikasi tersebut.(Fauzi \& Munastiwi, 2020: 174)

Sebagaimana ketika dilihat dari segi positif dan negative pembelajaran online tersebut, bagi dunia kependidikan mendapatkan berbagai hikmah. Diantaranya, pada peserta didik dan guru dapat menguasai teknologi sebagai bahan menunjang pembelajaran secara online ini. Di era millennial ini, teknologi yang semakin canggih atau pada zaman modern, guru maupun siswa dituntut agar memiliki sebuah kemampuan dalam bidang teknologi pembelajaran. Penguasaan siswa maupun guru terhadap teknologi pembelajaran mempunyai variasi dalam pebguasaannya, menjadikan sebuah tantangan tersendiri bagi mereka yang andil dalam dunia kependidikan. Dengan adanya kebijakan Work From Home (WFH), maka mampu memaksa dan mempercepat mereka dalam menguasai teknologi

17 (Fitriyani Nur Ivah, "MODEL PEMBELAJARAN ONLINE (DARING) MENGGUNAKAN GOOGLE CLASSROOM PADA MATA PELAJARAN PENDIDIKAN AGAMA ISLAM DAN BUDI PEKERTI DI SMPN 4 AMBARAWA.” INSTITUT AGAMA ISLAM NEGERI SALATIGA 2020: 2) 
pembelajaran secara digital sebagai suatu kebutuhan bagi mereka. Tuntutan kebutuhan tersebut, membuat mereka dapat mengetahui tentang media online yang dapat menunjang sebagai pengganti pembelajaran di kelas secara langsung (system tatap muka), tanpa mengurangi kualitas materi pembelajaran sedikitpun dan tanpa mengurangi target pencapaian dalam pembelajaran.

Sebagai bahan tolak ukur dalam menentukan keberhasilan pembelajaran yang bergantung kepada ketercapaiannya tujuan kompetensi belajar siswa, yang meliputi antara lain: kompetensi kognitif, psikomotorik, afektif serta perwujudan dari suatu penerapan nilainilai yang baik dalam berfikir ataupun bertindak. Adapun juga dapat memastikan untuk seluruh peserta didik agar memiliki penguasaan kompetensi materi ajar untuk kemudian akan melanjutkan kemateri selanjutnya merupakan maksud dari hasil ketuntasan belajar. Dalam ketuntasan belajar ini dapat merujuk kepada kompetensi-kompetensi yang dicapai serta ditunjang dengan sebuah indikator guna dalam mengukur suatu tingkat ketercapaiannya. Dalam semua aspek ketuntasan belajar ini hanya dapat dicapai dengan kolaborasi dan kerjasama antara kedua belah pihak yaitu guru dan siswa.

Berbagai manfaat dengan adanya pembelajaran daring seperti memacu sebuah kemandirian belajar pada siswa menjadikan dampak dalam pembelajaran secara daring. Sebab saat berjalannya proses belajar siswa mungkin tidak didampingi langsung oleh guru atau dosen sehingga dengan adanya proses memperoleh informasi yang lebih kompleks ataupun pertanyaan-pertanyaan meraka yang harus dijawab secara mandiri dengan mencoba untuk mengeksplorasi serta mengumpulkan data informasi dan pengetahuan sendiri baik dalam materi maupun penugasan yang telah diberikan oleh guru. Dalam sebuah pengumpulan informasi dan mengeksplorasi materi dimana peserta didik mendapatkan informasi tersebut dengan cara membaca buku, jurnal, artikel bahkan bisa juga melalui diskusi dengan teman-temannya serta melalui kegiatan literasi atau aktivitas-aktivitas yang berkaitan dengan materi tersebut ${ }^{18}$

Pembelajaran di masa pandemi Covid-19 seluruhnya dilaksanakan dengan cara system daring baik syncronous (langsung) maupun asyncronous (tidak langsung) demi tetap berjalannya program pembelajaran meskipun tidak secara langsung atau disebut dengan pembelajaran daring. Melalui pembelajaran daring siswa dapat belajar seperti biasanya dan

\footnotetext{
18 (Firdaus, "Implementasi Dan Hambatan Pada Pembelajaran Daring Di Masa Pandemi Covid 19." utile: Jurnal Kependidikan 6(2), 2020: 223) 230 | Ilmu Al-Qur'an (IQ) Jurnal Pendidikan Islam | Volume 04 No.2 2021
} 
tidak akan ketinggalan materi pembelajaran, karena waktu yang dirasakan lebih fleksibel. Namun, pembelajaran daring tidak disambut dengan baik ileh seluruh peserta didik, karena terdapat sebagian peserta didik yang menganggap bahwa pembelajaran daring ini mempunyai tingkat kesulitan yang lebih dibandingkan dengan pembelajaran konvensional (tatap muka). Hal tersebut ditambah dengan adanya tuntutan terhadap kuota internet yang harus selalu tersedia. Sebab ini merupakan menjadi kesulitan terbesar yang dialami oleh siswa. Kendala lain yang dihadapi oleh para siswa adalah buruknya koneksi internet di daerah tempat tinggal siswa, dan ketersediaannya perangkat pembelajaran seperti laptop. Siswa merasakan sebuah kesulitan bahwa tingkat pemahaman materi relatif lebih baik pada proses pembelajaran tatap muka secara langsung didalam kelas. Kendala lainnya adalah tidak semua guru dan siswa siap mengoperasikan sistem pembelajaran daring dengan cepat dan tepat, termasuk juga mempersiapkan bahan pembelajaran secara digital. ${ }^{19}$

Dengan adanya penerapan social distanding (pembatasan suatu interaksi social) juga berdampak dalam dunia kependidikan. Pemerintah telah membuat keputusan untuk meliburkan atau memindahkan proses pembelajaran yang tadinya di sekolah menjadi di rumah. Peralihan dalam pembelajaran ini memperlibatkan berbagai pihak untuk mengikuti alur yang sekiranya dapat ditempuh agar pembelajaran bisa berlangsung dengan cara memanfaatkan sebuah teknologi sebagai media pembelajaran daring (online).

Dalam penggunaan teknologi ini, sebenarnya terdapat beberapa masalah antara lain tentang penguasaan teknologi yang masih rendah, adanya keterbatasan sarana dan prasarana, jaringan internet, biaya, dan motivasi guru serta minat siswa yang menurun karena bosan menggunakan teknologi tersebut.

Di masa pandemi covid 19 ini cara yang dilakukan suatu pihak sekolah untuk pembelajaran tetap berlangsung antar lain biasanya dengan menerapkan pembelajaran daring dan pembelajaran luring. Meskipun terkadang tujuan pembelajaran yang ingin di sampaikan belum tercapai dengan maksimal, akan tetapi di harapkan perserta didik dapat menerima pembelajaran dengan baik terlait pembelajaran daring ataupun pembelajaran luring sebagai pengganti pembelajaran tatap muka. Kebijakan tersebut salah satu upaya yang di lakukan oleh pihak sekolah untuk mencerdaskan peserta didiknya.

19 (Ely Satiyasih Rosali, Jurusan Pendidikan, and Geografi Universitas. 2020. "AKTIFITAS PEMBELAJARAN DARING PADA MASA PANDEMI COVID -19 DI." Geography Science Education Journal (GEOSEE 1(1), 2020: 23) 
Adapun istilah pembelajaran daring dan luring di perkenalkan di era teknologi informasi pada saat ini, pembelajaran daring yaitu sebuah singkatan dari pembelajaran dalam jaringan, atau sebagai pengganti istilah pembelajaran online yang sering kita gunakan dalam teknologi internet. ${ }^{20}$

Adanya sistem pembelajaran daring dan luring ini mau tidak mau harus dilakukan di tengah wabah covid-19. karena, tidak mungkin peserta didik dibiarkan begitu saja atau dilaksanakannya libur panjang hingga menggunggu covid 19 akan hilang. Dalam pembelajaran daring dan luring di sekolah ini pada masa pandemi covid-19 mempunyai beberapa kendala seperti halnya keterbatasan waktu pembelajaran dan menyebabkan materi yang disampaikan pada proses pembelajaran terlalu sedikit. Adapun juga pembelajaran luring mempunyai kelemahan yaitu terkendala dengan adanya internet yang lemot dan kuota internet yang sangat terbatas. ${ }^{21}$

\section{Kesimpulan}

Pada penerapan aplikasi google classroom yaitu cara pelaksanaannya dengan melakukan kordinasi kepada guru yang telah menjalankan pembelajaran online dan bekerja sama antara bapak ibu guru wali kelas terkait mendata semua siswa yang sudah bisa terhubung pada pembelajaran dengan cara mengabsen daftar kehadiran dan siswa yang belum dapat terhubung, setelah itu baru membuka program jam pembelajaran, dan juga mencari sebuah solusi dalam menghadapi kendala tersebut mengenai siswa yang tidak bisa yerhubung dengan pembelajaran online tersebut agar kedepannya lebih baik ketika ada system pembelajaran daring lagi.

Pada faktor yang menjadi sebuah pendukung pembelajaran online dengan menggunakan aplikasi classroom ini yaitu tersedianya sarana prasarana disekolah yaitu dengan adanya pemasangan jaringan koneksi internet di sekolahan untuk mensupport system pembelajaran daring online. Sedangkan faktor yang menjadi penghambat yaitu dalam kendala yang sering dihadapi para orang tua peserta didik adalah adanya penambahan biaya untuk pembelian kuota internet. Adapun solusi untuk mengatasi dampak negatif dari pembelajaran online ini yaitu pemanfaatan sarana dan prasarana dapat dimanfaatkan secara optimal agar dapat menunjang efektifitas pembelajaran online. Adapun caranya yaitu dengan cara

\footnotetext{
${ }^{20}$ (Rio Erwan Pratama, dan Sri Mulyati, "Pembelajaran Daring Dan Luring Pada Masa Pandemi Covid19." Gagasan Pendidikan Indonesia 1(2), 2020: 52)

${ }^{21}$ (Rio Erwan Pratama, dan Sri Mulyati, "Pembelajaran Daring Dan Luring Pada Masa Pandemi Covid19." Gagasan Pendidikan Indonesia 1(2), 2020: 51)

232 | Ilmu Al-Qur'an (IQ) Jurnal Pendidikan Islam | Volume 04 No.2 2021
} 
pemberian modul pembelajaran untuk materi yang belum tersampaikan, dan terkait siswa yang belum bisa dapat terhubung dalam pembelajaran disarankan untuk datang kesekolah untuk mengambil tugas.

\section{Saran}

Disarankan bagi mahasiswa yang nantinya akan melakukan penelitian terkait pada judul tersebut lebih baiknya mengupas lebih mendalam terkait judul penelitian yang sama. Agar mendapatkan teori atau penemuan yang lebih baru dan menjadikan motivasi bagi semua pembaca karya ilmiah ini. Saran untuk lembaga pendidikan ditujukan oleh pihak yang bertugas di sekolah tersebut agar lebih menyiapkan sarana prasaran proses pembelajaran daring sebagai penunjang proses pembelajaran daring ketika pembelajaran dilakukan dengan sistem daring lagi untuk dimasa yang akan datang agar tidak terjadi lagi kendala atau masalah yang serupa dengan tahun ini.

\section{Daftar Pustaka}

Amamah, Haniq. "PENINGKATAN PRESTASI BELAJAR SISWA MAPEL AL-QUR'AN HADITS MATERI SURAH AL-BAYYINAH MELALUI PENERAPAN METODE DRILL KELAS VI MI NASHRIYAH MRANGGEN TAHUN.” UNIVERSITAS ISLAM NEGERI WALISONGO, 2016.

Baldwin, S, Y. H. Ching, and Y. C Hsu. "Online Course Design in Higher Education." $A$ Review of National and Statewide Evaluation Instruments 62, no. 1 (2018): 46-57.

Fauzi, Wildan Nuril Ahmad, and Erni Munastiwi. “ANALISIS PROSES PEMBELAJARAN BERBASIS ONLINE MASA PANDEMI COVID-19 DI SDIT LUQMAN AL-HAKIM SLEMAN" 14, no. 2 (2020): 171-86.

Firdaus, Firdaus. "Implementasi Dan Hambatan Pada Pembelajaran Daring Di Masa Pandemi Covid 19." Utile: Jurnal Kependidikan 6, no. 2 (2020): 220-25.

Fitrotun, Naili Nur, Moh Miftakhul Huda, and Achmad Ali Fikri. "Persepsi Calon Guru PAI Terhadap Merdeka Belajar.” Tadris:Jurnal Pendidikan Islam 14, no. 1 (2019): 1-12.

Hagermoser Sanetti, Lisa M., Kathleen M. Williamson, Anna C.J. Long, and Thomas R.

Kratochwill. "Increasing In-Service Teacher Implementation of Classroom Management Practices Through Consultation, Implementation Planning, and Participant Modeling." Journal of Positive Behavior Interventions 20, no. 1 (2018): 43-59.

Hammi, Zedha. “'Implementasi Google Classroom Pada Kelas Xi Ipa Man 2 Kudus.” Skripsi. 
Moh. Miftakhul Huda, Ashif Az Zafi

Universitas Negeri Semarang, 2017.

Ivah, Fitriyani Nur. "MODEL PEMBELAJARAN ONLINE (DARING) MENGGUNAKAN GOOGLE CLASSROOM PADA MATA PELAJARAN PENDIDIKAN AGAMA ISLAM DAN BUDI PEKERTI DI SMPN 4 AMBARAWA.” INSTITUT AGAMA ISLAM NEGERI SALATIGA, 2020.

Magdalena, Ina, Azza Salsabila, Diah Ajeng Krianasari, Shabira Fairuza Apsarini, and Universitas Muhammadiyah Tangerang. "Implementasi Model Pembelajaran Daring Pada Masa Pandemi Covid-19 Di Kelas Iii Sdn Sindangsari Iii." Pandawa : Jurnal Pendidikan Dan Dakwah 3, no. 1 (2020): 119-28.

Martono, Nanang. Metode Penelitian Sosial. Jakarta: Rajawali Pers, 2015.

Mulatsih, Bekti. "Penerapan Aplikasi Google Classroom, Google Form, Dan Quizizz Dalam Pembelajaran Kimia Di Masa Pandemi Covid-19 Application of Google Classroom , Google Form and Quizizz in Chemical Learning During the Covid-19 Pandemic." Ideguru: Jurnal Karya Ilmiah Guru 5, no. 1 (2020): 16-26.

Pratama, Rio Erwan, and Sri Mulyati. "Pembelajaran Daring Dan Luring Pada Masa Pandemi Covid-19." Gagasan Pendidikan Indonesia 1, no. 2 (2020): 49.

Rosali, Ely Satiyasih, Jurusan Pendidikan, and Geografi Universitas. "AKTIFITAS PEMBELAJARAN DARING PADA MASA PANDEMI COVID -19 DI." Geography Science Education Journal (GEOSEE 1, no. 1 (2020): 21-30.

Say, Fuat Serkan, and Fatih Serdar Yildirim. "Flipped Classroom Implementation in Science Teaching." International Online Journal of Education and Teaching 7, no. 2 (2020): 60620.

Soni, Afdhil Hafid, Regiolina Hayami, Yulia Fatma, Febby Apri Wenando, Januar Al Amien, Evans Fuad, Mitra Unik, Harun Mukhtar, and Hasanuddin. "Optimalisasi Pemanfaatan Google Classroom Sebagai Media Pembelajaran Di SMK Negeri 1 Bangkinang.” Jurnal Pengabdian Untuk Mu NegeRI 2, no. 1 (2018): 17-20.

Tibahary, Abdul Rahman, and Muliana. "MODEL-MODEL PEMBELAJARAN INOVATIF Muliana" 1, no. 03 (2018): 54-64.

Umroh, Afidatul. "Peran Guru Pendidikan Agama Islam Dalam Menginternalisasikan NilaiNilai Pendidikan Islam Untuk Menumbuhkan Sikap Toleran Antar Umat Beragama Siswa Kelas XI SMK N 5 Yogyakarta.” UIN Sunan Kalijaga Yogyakarta, 2015.

Vrba, Tony, and Kerry Mitchell. “Contemporary Classroom Innovation: Exploration.” Journal of Instructional Pedagogies 22 (2019): 1-8. 
Penerapan Aplikasi Classroom pada Mata Pelajaran Qur'an Hadits

Winarno, W., and J Setiawan. "Penerapan Sistem E-Learning Pada Komunitas Pendidikan Sekolah Rumah (Home Schooling).” Jurnal ULTIMA InfoSys, 4, no. 1 (2013). 